\title{
AKTIVITAS MEDIA RELATIONS PEGAWAI HUMAS DI PEMERINTAH PROVINSI SULAWESI SELATAN
}

\author{
Rahmita Saleh \\ Fakultas Ekonomi dan Ilmu Sosial, Universitas Fajar \\ mita.saleh@gmail.com
}

\begin{abstract}
Abstrak
Penelitian ini bertujuan untuk menggambarkan aktivitas media relations yang dijalankan oleh pegawai humas di Pemerintah Provinsi Sulawesi Selatan dalam berkomunikasi dengan publik. Dalam penelitian ini digunakan pendekatan deskriptif kualitatif dengan menggunakan teknik pengumpulan data melalui wawancara mendalam dan observasi terhadap pegawai humas yang bertugas melakukan kegiatan media relations. Teknik analisis data menggunakan model interaktif Huberman dan Miles yang ditempuh melalui tahap reduksi data, display data, pengambilan kesimpulan dan verifikasi. Hasil penelitian menunjukkan bahwa pegawai humas di Pemerintah Provinsi Sulawesi Selatan melakukan kegiatan media relations berdasarkan tupoksi (tugas pokok dan fungsi) Sub Bagian Publikasi dan Sub Bagian Pengumpulan dan Penyaringan Informasi yaitu menyiapkan bahan penyelenggaraan keterangan pers dan rencana penyelenggaraan konferensi pers; melakukan kerjasama kemitraan dengan kalangan media; menyiapkan peliputan acara kegiatan Pemerintah Provinsi Sulawesi Selatan dengan mengundang pers serta menyiapkan bahan-bahan siaran pers; menyiapkan, merencanakan dan menyebarluaskan kegiatan Pemerintah Provinsi Sulawesi Selatan dalam press release melalui media massa; melakukan pengumpulan dan penyaringan informasi sebagai bahan pengambilan kebijakan dan untuk kepentingan publikasi atau pemberitaan serta kepentingan lain; dan memberi akses kepada sumber informasi. Penelitian ini menyimpulkan bahwa aktivitas media relations yang dijalanan pegawai humas di Pemerintah Provinsi Sulawesi Selatan lebih bersifat reaktif dan fokus untuk menyediakan informasi kepada media massa tetapi tidak berupaya menyesuakan dengan kebutuhan media massa.
\end{abstract}

Kata Kunci: Media Relations, Humas Pemerintah, Media Massa

\section{PENDAHULUAN}

Pemerintah Provinsi Sulawesi Selatan (Pemprov Sulsel) sejak pertama kali mendapat penilaian terbaik dari Badan Pemeriksa Keuangan Republik Indonesia (BPK RI) terhadap pengelolaan anggaran sejak tahun 2010 hingga saat ini telah tiga kali berturut-turut mendapatkan opini Wajar Tanpa Pengecualian (WTP). Saat ini Pemprov Sulsel juga memprioritaskan pembangunan infrastruktur khususnya pembangunan 11 ruas jalan dengan mengusulkan Anggaran Pendapatan dan Belanja Daerah (APBD) sebesar Rp 5,79 Triliun (www.antarasulsel.com).
Penilaian laporan keuangan yang baik dari BPK menunjukkan bahwa Pemprov Sulsel mampu mempertahankan kualitas penyajian Laporan Keuangan Daerah. Ini juga harus sejalan dengan transparansi mulai dari penyampaian informasi mengenai program hingga gambaran penggunaan anggaran yang dapat dipertanggungjawabkan kepada publik. Tugas ini merupakan kewenangan humas yang harus dapat menyediakan dan menyajikan informasi kepada publik melalui kegiatan media relations dengan memanfaatkan media massa sebagai sarana untuk menyebarluaskan informasi dan 
transparansi dalam penyelenggaraan pemerintahan dan pembuatan kebijakan.

Salah satu bentuk media relations yang rutin dijalankan humas Pemprov Sulsel adalah menginformasikan agenda kerja pemerintah setiap hari kepada wartawan untuk diliput. Strategi ini cukup efektif karena informasi tersebut juga sangat dibutuhkan oleh wartawan untuk menjadi agenda liputan. Tetapi tugas media relations humas lebih dari pada itu, humas juga harus menyediakan informasi yang mereka anggap pantas untuk diberitakan dengan harapan editor dan reporter akan menggunakan informasi tersebut. Selain itu praktisi humas juga harus memahami kerja media, yaitu memahami bagaimana cara bekerja sama dengan setiap medium, cara menghasilkan isi untuk masing-masing media, cara memenuhi persyaratan spesifik dan menangani audiens media. Seperti yang disarankan Iriantara (2005:142), menurutnya salah satu prasyarat yang diperlukan untuk menjalin hubungan baik dengan media adalah dengan mengenal media massa itu. Setelah itu baru dilanjutkan dengan tahap memenuhi kebutuhan dan keinginan media massa.

Penting juga dipahami bahwa melalui media relations, pemerintah dapat memberikan informasi untuk diketahui banyak orang sehingga pemerintah dapat menyajikan pertanggungjawaban karena dikontrol oleh publik. Sehingga, dengan adanya transparansi dalam penyelanggaraan pemerintahan, dapat menjamin akuntabilitas pembuat kebijakan kepada publik dan mencegah terjadinya penyalahgunaan. Oleh karena itu, peran pegawai humas sangatlah strategis dan penting. Hal inilah yang mendasari dilakukan penelitian untuk mengetahui gambaran aktivitas media relations yang dijalankan oleh pegawai humas di Pemerintah Provinsi Sulawesi Selatan dalam berkomunikasi dengan publik dalam menyajikan transparansi penyelenggaraan pemerintahan.

\section{Rumusan Masalah}

Bagaimana bentuk aktivitas media relations yang dijalankan pegawai humas di Pemerintah Provinsi Sulawesi Selatan?

\section{Tujuan Penelitian}

Penelitian ini bertujuan untuk mendapatkan gambaran dan menganalisis aktivitas media relations yang dijalankan pegawai humas di Pemerintah Provinsi Sulawesi Selatan.

\section{Manfaat Penelitian}

Manfaat yang diharapkan dapat diperoleh dari penelitian ini adalah dapat mengembangkan kajian studi ilmu komunikasi khususnya dalam bidang Public Relations dan Jurnalistik. Penelitian ini juga diharapkan dapat memberi masukan bagi para pegawai humas pemerintah, khususnya humas Pemerintah Provinsi Sulawesi Selatan dalam melakukan kegiatan media relations.

\section{TINJAUAN PUSTAKA Hubungan masyarakat}

Hubungan masyarakat atau yang sering disingkat humas atau public relations (PR) merupakan sebuah fungsi manajemen yang dalam konteks ilmu komunikasi, sebagai metode dan teknik komunikasi, humas termasuk di dalam bidang komunikasi manajemen yang sering juga disebut komunikasi organisasional.

Sebagai sebuah fungsi manajemen Cutlip, Center dan Broom (2009:6) dalam bukunya Effective Public Relations mendefinisikan PR adalah fungsi manajemen yang membangun dan mempertahankan hubungan yang baik dan bermanfaat antara organisasi dengan publik yang memengaruhi kesuksesan atau kegagalan organisasi tersebut.

Dalam konteks public relation, sasaran kegiatan sebuah organisasi bukan saja orang-orang di luar organisasi yang berkepentingan dengan organisasi itu, tetapi juga orang-orang yang berada di dalam organisasi bersangkutan. Oleh karena itu, hubungan masyarakat 
mempunyai dua pengertian yaitu sebagai teknik komunikasi dan metode komunikasi.

Dalam sebuah organisasi yang tidak dilengkapi dengan Bagian Humas, tidak berarti tidak ada kegiatan kehumasan. Sebagai contoh, sebuah kecamatan. Oleh karena daerahnya relatif kecil dan jumlah penduduk yang menjadi sasaran kegiatannya juga relatif kecil, serta jumlah pegawai yang membantunya relatif kecil pula, maka biasanya tidak dibentuk secara khusus Bagian Humas, yang bertanggung jawab pada kegiatan kehumasan adalah Kepala Kecamatan. Inilah yang merupakan pengertian humas sebagai teknik komunikasi atau keterampilan berkomunikasi.

Sedangkan sebagai metode komunikasi, sering disebut humas sebagai lembaga dan umumnya hanya terdapat pada organisasi-organisasi besar karena kegiatan berkomunikasi dengan publik tidak mungkin dilakukan oleh seorang pemimpin organisasi. Jadi, teknik-teknik komunikasi yang seharusnya dilakukan oleh pimpinan organisasi dilembagakan kepada seseorang yang ditugaskan untuk mengepalainya yang lazim disebut Kepala Humas yang merupakan terjemahan dari public relations officer (PRO).

\section{Hubungan Masyarakat Pemerintah}

Humas pemerintah atau biasa disebut pejabat public affairs atau pejabat penerangan atau PRO adalah penghubung penting antara rakyat dengan pemerintah. Dalam pengertian yang riil, tujuan humas pemerintah sesuai dengan tujuan organisasi. Informasi yang melimpah dan akurat digunakan oleh pemerintah yang demokratis untuk menjaga hubungan yang responsive dengan konstituen, berdasarkan pada pemahaman bersama dan komunikasi dua arah yang terus menerus.

Oleh karena pemerintah menyentuh setiap aspek masyarakat dan hampir semua bagian pemerintah kini mengandalkan humas, maka tujuan dari keberadaan humas dalam pemerintah adalah (Cutlip, Center dan Broom, 2009:466):
a. Memberi informasi konstituen tentang aktivitas agen pemerintah
b. Memastikan kerja sama aktif di dalam program pemerintah
c. Mendorong warga mendukung kebijakan dan program yang sudah ditetapkan (membangun dukungan warga negara)
d. Melayani sebagai advokat publik untuk administrator pemerintah
e. Mengelola informasi internal
f. Memfasilitasi hubungan media
g. Membangun komunitas dan bangsa.

\section{Media Relations}

Istilah media relations atau
hubungan dengan media massa mengandung makna terbinanya hubungan kepala humas dengan orang-orang yang bekerja di media massa seperti redaktur surat kabar dan majalah, wartawan radio dan reporter televisi. Kepala humas perlu membina hubungan yang akrab dengan orang-orang media massa agar segala sesuatu yang menyangkut penyebaran informasi kepada publik ekstern berjalan lancar.

Disamping itu, apabila terdapat suatu informasi yang bisa merugikan organisasi, ada kemungkinan wartawan yang memperoleh informasi tersebut, sebelum memberitakannya terlebih dahulu menanyakan kepada kepala humas mengenai kebenarannya.

Memahami media, yaitu memahami bagaimana cara bekerja sama dengan setiap medium, cara menghasilkan isi untuk masing-masing media, cara memenuhi persyaratan spesifik dan menangani audiens media adalah bagian utama dari tugas kepala humas. Dalam rangka pembinaan hubungan dengan media massa, mengutip pendapat Arthur Roalman dalam bukunya "Profitable Public Relations" (Effendy, 2002:119-120) bahwa hubungan dengan pers yang baik perlu 
dibina dengan memperhatikan beberapa asas-asas, yaitu:

a. Orang pers yang dilibatkan harus yakin bahwa orang-orang organisasi yang bekerja dengannya tidak mencoba untuk menggunakannya.

b. Hubungan dengan wartawan hendaknya dilakukan seolah-olah dengan tujuan yang sungguhsungguh untuk terus berhubungan selama bertahun-tahun.

c. Orang-orang pers secara fundamental berkaitan dengan ketelitian.

d. Rencana pemberitaan harus dihormati. Untuk editorial, waktu selamanya merupakan suatu faktor.

e. Tulisan yang baik bersifat esensial. Terdapat banyak hal untuk diceritakan bagi pemikiran yang gamblangguna dinyatakan secara sederhana.

f. Berupaya untuk menimbulkan imajinasi dan kesegaran terdapat banyak hal untuk diceritakan untuk pendekatan baru terhadap suatu persoalan.

Itulah sebabnya, media berita menjadi faktor utama dalam humas, yang mengontrol arus publisitas melalui saluransaluran komunikasi umum yang sangat penting. Frazier Moore (2005:194) menekankan pentingnya memilih media yang sesuai untuk publisitas. Menurutnya pemilihan media yang sesuai adalah esensial untuk persiapan dan penyebaran siaran berita.

\section{METODE PENELITIAN \\ Lokasi dan Waktu Penelitian}

Penelitian ini dilaksanakan di kantor Biro Humas dan Protokol yang bertempat di Jalan Jenderal Urip Sumoharjo No. 269 Makassar yang merupakan pusat aktivitas pegawai Biro Humas dan Protokol Pemerintah Provinsi Sulawesi Selatan dalam menjalankan kegiatan kehumasan sehari-hari. Waktu penelitian dilaksanakan selama tiga bulan, yaitu bulan April hingga Juli 2014.

\section{Tipe Penelitian}

Penelitian ini menggunakan pendekatan kualitatif. Tipe yang digunakan adalah deskriptif, yang berupaya menggambarkan, mengungkapkan, menjelaskan dan menganalisis karakteristik hubungan humas kepada media massa sebagai sasaran operasional pelaksanaan kegiatan media relations di kantor Pemerintah Provinsi Sulawesi Selatan. Humas Pemerintah Provinsi Sulawesi Selatan sebagai aspek internal organisasi publik, menjadi fokus penelitian sebagai fenomena mikro. Sedangkan aktivitas media relations sebagai fenomena makro.

\section{Informan Penelitian}

Informan dalam penelitian ini adalah pegawai Biro Humas dan Protokol di Pemerintah Provinsi Sulawesi Selatan yang bertanggung jawab pada kegiatan media relations yang berjumlah 13 orang, yaitu Kepala Biro Humas dan Protokol, Kepala Bagian Humas, Kepala Sub Bagian Publikasi, Kepala Sub Bagian Pengumpulan dan Penyaringan Informasi, satu orang staf humas yang bertugas sebagai Reporter dan delapan orang staf humas yang bertugas sebagai Fotografer.

\section{Teknik Pengumpulan Data}

Pengumpulan data dilakukan melalui observasi, wawancara mendalam dan dokumentasi. Observasi dilakukan selama masa penelitian dengan mengamati langsung aktivitas media relations yang dilakukan oleh pegawai humas, baik yang dilakukan di dalam maupun di luar kantor Biro Humas dan Protokol. Wawancara mendalam dilakukan kepada seluruh informan untuk menggali informasi sebanyak-banyaknya untuk dijadikan data dan kesimpulan dalam penelitian. Dokumentasi dilakukan untuk mengumpulkan data-data lainnya terkait aktivitas media relations yang dilakukan oleh pegawai Biro Humas dan Protokol 
seperti bentuk kerjasama, foto, press release, dan sebagainya.

\section{Teknik Analisis Data}

Untuk menganalisis data, penulis melakukan beberapa tahapan. Pertama, menganalisis hasil wawancara dan dokumentasi menggunakan model interaktif Huberman dan Miles dengan dengan mereduksi data yang sesuai dengan fokus penelitian tentang aktivitas media relations. Kedua, membuat kategorikategori tematik dari data yang telah terkumpul. Ketiga, ditarik kesimpulan sementara dan terus melakukan verifikasi dengan mengumpulkan data baru hingga dapat ditarik kesimpulan yang benar.

\section{HASIL DAN PEMBAHASAN Hasil Penelitian}

Aktivitas media relations yang dilakukan oleh pegawai humas Pemerintah Provinsi Sulawesi Selatan meliputi:

\section{Menginformasikan agenda kerja Pemerintah Provinsi Sulawesi Selatan kepada wartawan}

Aktivitas media relations yang paling rutin dilakukan oleh pegawai Biro Humas dan Protokol adalah memberi informasi agenda kerja Gubernur, Wakil Gubernur dan Sekretaris Daerah kepada wartawan. Hal ini diungkapkan oleh Kepala Sub Bagian Publikasi pada wawancara pada tanggal 17 April 2014:

"Bagian publikasi menangani kegiatankegiatan publikasi untuk agenda Gubernur, Wakil Gubernur dan Sekretaris Daerah. Khusus pada kegiatan yang berhubungan dengan media, untuk setiap agenda Gubernur, Wakil Gubernur dan Sekretaris Daerah yang diberikan oleh Bagian Protokol, diinformasikan kepada wartawan yang posting di humas. Tetapi tidak semua kita informasikan, kita sortir dulu mana yang layak diketahui publik, itulah yang kita informasikan kepada wartawan."

Secara teknis, bentuk penyampaian informasi agenda pemerintah kepada wartawan disampaikan oleh Kepala Sub Bagian Pengumpulan dan Penyaringan
Informasi, Badaruddin, dalam wawancara yang dilakukan pada tanggal 5 Mei 2014:

"Pertama, sebelum acara besok, kami sudah mendapat agenda harian dari Protokol untuk kegiatan pemerintah provinsi. Setelah itu kami kirimkan melalui BBM atau sms kepada media yang posting di kantor gubernur juga kepada mediamedia nasional dan media lain yang tidak bekerja sama dengan pemerintah provinsi."

\section{Menyelenggarakan konferensi pers}

Kepala Biro Humas dan Protokol, Andi Darmawan Bintang, pada wawancara yang dilakukan pada tanggal 21 April 2014 menjelaskan bahwa salah satu aktivitas Biro Humas dan Protokol adalah menyiapkan konferensi pers, khususnya untuk kebijakan yang bersifat strategis. Berikut kutipan wawancaranya:

"Dalam pemberitaan, selalu dijalin komunikasi dengan wartawan, setiap ada acara, wartawan dipanggil atau wartawan yang mencari berita ke humas. Kalau misalnya suatu berita atau yang ingin diberitakan mengenai pemerintah Provinsi apakah itu aktivitas ataupun kebijakan yang strategis itu biasanya dilakukan konferensi pers dengan memanggil wartawan. Pak Gubernur langsung memberikan keterangan pers pada saat ada berita yang muncul secara sporadis dan berkembang di masyarakat dan itu penting untuk diberikan penjelasan segera dan secara langsung."

Kegiatan ini berada di bawah tanggung jawab Kepala Sub Bagian Publikasi yang dipimpin oleh Amrullah Hanafie. Secara teknis, alur pelaksanaan konferensi pers dapat dilihat dalam Gambar 1, seperti yang dijelaskan oleh Kepala Sub Bagian Publikasi (wawancara pada tanggal 17 April 2014):

"Untuk jumpa pers, informasi yang akan disampaikan ke media ditangani oleh Kasubag Pengumpulan dan Penyaringan Informasi dan kegiatannya dikelola oleh Sub Bagian Publikasi. Biasanya jumpa pers juga diusulkan oleh sumber seperti Gubernur, Wakil Gubernur, Asisten, Kepala Dinas dan lain-lain kepada humas, disini kemudian dibuat jadwal pelaksanaan, waktu, tempat dan apa-apa yang akan disampaikan atau releasenya kemudian diinformasikan ke wartawan." 
Selain itu, Biro Humas dan Protokol juga menyelenggarakan konferensi pers secara rutin di Press Room kantor Gubernur Provinsi Sulawesi Selatan setiap hari jum'at. Kepala Bagian Humas, Devo Khadafi, menjelaskan hal tersebut dalam wawancara pada tanggal 7 Mei 2014:

"Ada beberapa keluhan dari temanteman media bahwa kadang-kadang masih ada SKPD atau pimpinan yang kadang-kadang susah untuk dikonfirmasi terkait sebuah pemberitaan. Kita mencoba menjembatani dengan membuat sebuah program setiap jum'at yang kita beri nama meet the press. Meet the press ini ditujukan agar setiap SKPD yang diminta oleh teman-teman media kita coba komunikasikan apakah pimpinan SKPDnya mempunyai waktu untuk bertemu dengan media kurang lebih satu jam untuk melakukan dialog dan tanya jawab terkait persoalan apa yang ingin ditanyakan oleh media. Waktunya pagi, pukul 11.00."

\section{Membuat press release dan menyebarluaskan kepada media massa}

Untuk menyampaikan informasi kepada masyarakat, biasanya Biro Humas dan Protokol juga menulis press release dan disebarluakan kepada media massa. Menurut Kepala Sub Bagian Publikasi, pegawai yang bertugas sebagai reporter, selain meliput agenda pemerintah, juga ditugaskan membuat press release. Contoh press release yang dikirim pegawai humas dan dimuat dalam media cetak dapat dilihat dalam Gambar 2. Press release tersebut nantinya akan dikirim ke bagian pengolahan media internal untuk dimuat dalam website resmi Pemerintah Provinsi Sulawesi Selatan maupun dikirim kepada wartawan jika ada permintaan. Berikut petikan wawancaranya (wawancara tanggal 17 April 2014):

"Kalau wartawan datang meliput untuk agenda yang diinformasikan, biasanya mereka tidak dikirimi lagi press release. Kecuali wartawan yang tidak datang meliput dan meminta informasi, mereka akan diberi press release. Tetapi kami tetap membuat karena itu akan di muat di website Pemerintah Provinsi Sulawesi Selatan."

\section{Menghasilkan foto berita}

Selain reporter, Biro Humas dan Protokol juga memiliki fotografer dan kamaraman untuk merekam setiap aktivitas pemerintah. Sehari-hari, aktivitas fotografer dan kameraman dibagi ke dalam tiga tim, yaitu tim yang bertugas meliput kegiatan Gubernur, Wakil Gubernur dan Sekretaris Daerah. Mereka bertugas melakukan peliputan dalam bentuk foto dan audio video dari seluruh agenda pemerintah setiap hari. Berikut pernyataan salah seorang fotografer humas, Raden Muhammad Alfateh (wawancara pada tanggal 5 Mei 2014):

"Foto yang saya beritakan adalah kegiatan Gubernur baik formal maupun non-formal seperti pelantikan, pembukaan dan penerimaan tamu negara."

Biasanya hasil liputan foto mereka dijadikan dokumentasi, dimuat di website ataupun dikirimkan kepada wartawan sesuai permintaan. Untuk foto yang dikirim kepada wartawan, Biro Humas dan Protokol mempercayakan setiap foto yang dihasilkan oleh fotografer humas untuk dikirimkan secara langsung kepada wartawan. Informasi ini diperoleh dari Kepala Sub Bagian Publikasi dalam wawancara yang dilakukan pada tanggal 17 April 2014:

"Setelah meliput mereka mengirim press release maupun gambar kepada wartawan dan pengolahan data elektronik menggunakan email masing-masing. Jadi humas itu adalah wartawannya wartawan."

\section{Memberi akses kepada sumber informasi}

Kegiatan media relations lainnya yang dilakukan Biro Humas dan Protokol adalah memberi akses kepada wartawan untuk mendapatkan informasi langsung dari sumber informasi. Kegiatan ini biasanya dilakukan jika menyangkut informasi yang layak diberitakan namun sifatnya teknis. Hal ini diungkapkan 
Kepala Biro Humas dan Protokol dalam wawancara pada tanggal 21 April 2014:

"Untuk berita yang bersifat teknis, juga menjadi bagian dari penjelasan yang diberikan Biro Humas dan Protokol secara makro, tetapi untuk informasi secara detail berada pada sektor bidang teknis yang terkait. Untuk itu, wartawan diberi informasi oleh Kepala Biro untuk menghubungi Kepala Dinas atau Kepala Bidang yang berkompeten terhadap pemberitaan tersebut. Terkait dengan pemberitaan dari media, biasanya langsung dikonfirmasi kepada Gubernur atau kepada saya."

Pernyataan Kepala Biro Humas dan Protokol juga senada dengan yang diungkapkan Kepala Bagian Humas dalam pernyataannya berikut ini (wawancara tanggal 7 Mei 2014):

"Biasanya kalau mereka mau informasi yang lebih dalam lagi mereka bertanya

"Kak, ini leading sector-nya dinas apa?", kami kemudian arahkan ke penanggung jawabnya. Jadi, humas ini berfungsi sebagai jembatan antara SKPD, pemerintah provinsi dalam hal ini dan dengan masyarakat, apapun itu."

\section{Melakukan kerjasama kemitraan dengan media massa \\ Biro Humas dan Protokol}

Pemerintah Provinsi Sulawesi Selatan juga melakukan kerjasama kemitraan dengan beberapa media massa, baik lokal maupun nasional. Bentuknya berupa kontrak dengan media yang sifatnya permanen untuk meliput aktivitas Gubernur, Wakil Gubernur dan Sekretaris Daerah, juga termasuk di dalam kerjasama tersebut adalah iklan, advertorial dan kolom berlangganan. Terkait kerjasama kemitraaan tersebut, Kepala Bagian Humas menjelaskan dalam wawancara pada tanggal 7 Mei 2014:

"Di humas ini hampir sebagian besar kegiatan berkoneksi dengan media massa. Karena di humas merupakan jembatan antara pemerintah provinsi dengan media massa maupun masyarakat. Kita memang menjadikan media massa sebagai mitra kita dimana semua kegiatan-kegiatan pemerintahan sepenuhnya diliput oleh media kecuali yang memang sifatnya tertutup. Dan memang di pemerintah provinsi ini ada media yang posting setiap hari yang berjumlah sekitar dua puluh media"

Kerjasama kemitraan ini bertujuan untuk menjalin hubungan baik dengan media massa, menurut Kepala Sub Bagian Publikasi terdapat 12 media massa yang menjalin kerjasama kemitraan dengan Biro Humas dan Protokol, yaitu Fajar TV, Makassar TV, Harian Fajar, Harian Seputar Indonesia, Koran Tempo, Berita Kota Makassar, Harian Rakyat Sulsel, kabarmakassar.com, Kantor Berita Antara, Harian Tribun Timur, RRI, dan Cakrawala.

\section{Menangani pemberitaan negatif}

Hal-hal yang terus diantasipasi oleh Biro Humas dan Protokol adalah adanya pemberitaan negatif dari media massa. Untuk itu, mereka telah membentuk tim untuk menangani langsung pemberitaan yang bersifat negatif. Terkait penanganan berita negatif, Kepala Bagian Humas melalui petikan wawancaranya berikut ini menjelaskan (wawancara tanggal $7 \mathrm{Mei}$ 2014):

"Pemberitaan negatif ataupun sesuatu yang sifatnya memberi citra negatif ke pemerintah, itu yang menjadi tugas dari Pak Badar (Kepala Sub Bagian Pengumpulan dan Penyaringan Informasi) untuk menyaring, kemudian hasilnya diberikan ke kami selaku pimpinan di Bagian Humas, kemudian kami yang akan berkoordinasi dengan SKPD terkait dengan isu-isu negatif. Kita mendapatkan informasi yang betul-betul up to date dan memang valid terkait dengan suatu permasalahan, setelah itu kita membuat lagi laporan ke pimpinan bahwa seperti ini permasalahannya dan kira-kira solusi atau jalan keluarnya seperti ini. Kalau untuk hal ini, tidak harus selalu berbentuk konferensi pers, bisa juga press release yang kami kirim, atau biasa juga temanteman media langsung menemui pimpinan SKPD untuk menjawab permasalahannya. Kecuali kalau masalahnya sudah melebar kemana-mana memang harus humas yang jawab."

Tetapi menurut Kepala Biro Humas dan Protokol, tidak semua pemberitaan negatif direspon oleh Biro Humas dan 
Protokol, berikut pernyataannya (wawancara tanggal 21 April 2014):

"Berita negatif tidak selalu harus kami respon karena kadang kami menganggap bahwa pemberitaan tersebut belum tentu harus kami klarifikasi. Terkadang media membuang dulu informasi, kalau kita tidak merasa melakukan sesuatu kita tidak perlu klarifikasi. Karena kalau kita klarifikasi, publik bisa menilai bahwa mungkin memang ada sesuatu yang terjadi. Jadi, tidak semua hal-hal patut kita klarifikasi biarlah media yang mencari informasinya.",

Upaya antisipasi terhadap pemberitaan media massa salah satunya adalah dengan membuat kliping beritaberita media cetak baik lokal maupun nasional yang terbit setiap hari yang memuat berita Pemerintah Provinsi Sulawesi Selatan. Upaya antisipasi lainnya adalah merekam setiap wawancara yang dilakukan oleh Gubernur. Ini adalah tugas yang kerjakan oleh Kepala Sub Bagian Pengumpulan dan Penyaringan Informasi. Berikut penyataannya (wawancara tanggal 5 Mei 2014):

"Selain menulis press release saya juga merekam setiap pembicaraan Gubernur. Gunanya, karena pimpinan banyak meminta off the record ketika wawancara, tetapi wartawan kadang kala pimpinan bilang off the record mereka tetap muat di medianya. Jadi, ketika terjadi polemik, saya perdengarkan dan katakan bahwa pimpinan sudah bilang off the record, kenapa tetap di muat? Semua yang saya rekam saya simpan di Sub Bagian Dokumentasi."

\section{Pembahasan}

Bentuk pelayanan komunikasi dan informasi kepada media atau dikenal dengan istilah media relations dapat dilakukan melalui beberapa kegiatan, yaitu mengirim siaran pers (press release), foto berita, mengadakan jumpa pers (press conference), mengadakan kegiatan khusus (special event), menjadi sumber informasi media massa (wawancara media), memberi akses kepada sumber informasi dan menangani publisitas negatif.

Jika mengacu pada pendapat Yosal Iriantara

(2005:189) mengkategorikan publisitas menjadi tiga kelompok kegiatan, maka bentuk pelayanan tersebut dapat berupa:

a. Kegiatan yang berkesinambungan, meliputi:
a) Keterlibatan organisasi dalam komunitas lokal
b) Keterlibatan organisasi pada komunitas industri
c) Penerbitan bulletin, majalah atau Koran perusahaan
d) Employee relations
e) Media relations
f) Foto dan media kit
g) Hubungan dengan pemegang saham, pemilik dan komunitas finansial

b. Kegiatan jangka pendek yang direncanakan sebelumnya (terencana), meliputi:
a) Siaran pers
b) Konferensi pers
c) Penyelenggaraan kegiatan, acara peringatan atau upacara pembuka
d) Pengumuman
e) Seminar untuk pers
f) Hasil penelitian pasar

c. Kegiatan jangka panjang untuk peristiwa yang tak terduga atau biasa dinamakan manajemen krisis, adalah:
a) Menangani publisitas negatif
b) Wawancara dengan media massa
Dalam pelaksanaannya, humas Pemerintah Provinsi Sulawesi Selatan melakukan kegiatan media relations melalui mekanisme kerja yang jelas sesuai dengan uraian tugas atau tupoksi (tugas pokok dan fungsi) yang diberikan kepada Sub Bagian Publikasi dan Sub Bagian Pengumpulan dan Penyaringan Informasi yang berada di bawah koordinasi Bagian Humas. Program atau kegiatan yang dilaksanakan adalah:

a. Menginformasikan agenda kerja Pemerintah Provinsi Sulawesi Selatan kepada wartawan (Tupoksi: menyiapkan peliputan acara 
kegiatan Pemerintah Provinsi

Sulawesi Selatan dengan mengundang pers serta menyiapkan bahan-bahan siaran pers)

b. Menyelenggarakan konferensi pers (Tupoksi: menyiapkan bahan penyelenggaraan keterangan pers dan rencana penyelenggaraan konferensi pers)

c. Membuat press release dan menyebarluaskan kepada media massa (Tupoksi: menyiapkan, merencanakan dan menyebarluaskan kegiatan Pemerintah Provinsi Sulawesi Selatan dalam press release melalui media massa)

d. Menghasilkan foto berita

e. Memberi akses kepada sumber informasi

f. Melakukan kerjasama kemitraan dengan media massa (Tupoksi: melakukan kerjasama kemitraan dengan kalangan media)

g. Menangani pemberitaan negatif (Tupoksi: melakukan pengumpulan dan penyaringan informasi sebagai bahan pengambilan kebijakan dan untuk kepentingan publikasi atau pemberitaan serta kepentingan lain)

Berdasarkan hasil wawancara dan observasi, dalam kegiatan yang berkaitan dengan media relations, humas lebih banyak berperan dalam kegiatan menjalin komunikasi dengan wartawan yang bertugas meliput di kantor Pemerintah Provinsi Sulawesi Selatan yaitu dengan memberikan informasi agenda kerja Gubernur, Wakil Gubernur dan Sekretaris Daerah untuk diliput, mereka juga membuat dan memberikan press release maupun foto tetapi tidak mempertimbangkan persyaratan berita yang biasa digunakan oleh wartawan.

Dengan hanya terfokus pada aktivitas menjalin komunikasi dengan para wartawan melalui informasi agenda kerja pemerintah, dan tidak menggunakan media massa untuk menyajikan informasi yang berimbang, dapat berakibat pada kurangnya informasi yang diperoleh masyarakat terhadap aktivitas, kebijakankebijakan dan layanan pemerintah sehingga tidak menjamin transparansi dalam penyelanggaraan pemerintahan.

$$
\text { Pun dengan mengabaikan }
$$

pentingnya menulis press release yang disesuaikan dengan kebutuhan masingmasing media massa (ditulis dalam gaya dan perspektif wartawan), informasi yang diharapkan dapat disampaikan ke masyarakat luas tidak dimanfaatkan oleh media massa disebabkan adanya penilaian mereka atas nilai dan kepentingan informasi tersebut bagi audiens mereka. Sehingga, agar dapat menarik perhatian media massa untuk memberitakan informasi yang diharapkan, pegawai humas harus tahu informasi apa yang bisa menarik perhatian media, mengidentifikasi sudut pandang berita yang layak, dan menulis serta mengemas informasi agar sesuai dengan mediumnya. Seperti yang diungkapkan oleh Frazier Moore (2005:198-199), meliput sumber berita organisasi yang sistematis dan teratur oleh seorang penulis dari staf publisitas adalah esensial untuk memperoleh berita agar dapat disebarkan kepada pers.

Pelaksanaan pengiriman berita dan artikel tanpa membeda-bedakan media dan tanpa pengetahuan mengenai isi redaksionalnya, khalayaknya dan kebijaksanaan redaksional media adalah percuma saja karena arus berita yang tidak bernilai membanjiri meja redaksi dan hanya memenuhi keranjang sampah mereka. Itu adalah salah satu praktek yang tidak efektif dalam humas, karena menurut Effendy (2002:121), media massa akan bersedia menyiarkan apabila siaran pers tersebut memenuhi persyaratan berita yang biasa digunakan oleh wartawan.

Oleh karena itu, dalam kegiatan media relations, peran humas secara khusus adalah memberikan informasi akurat dan tepat waktu kepada media tentang berbagai kebijakan, program dan aktivitas pemerintah dan membuat pemberitaan menjadi berimbang dan benar. 
Maka, dalam membangun hubungan dengan media, pihak pemerintah seharusnya memberi perhatian memadai kepada media dengan memberi kesempatan bagi media massa untuk berpartisipasi dalam program pemerintah dan selalu melakukan kontak media serta berbagi informasi melalui press release agar media selalu mengetahui isu di pemerintahan. Bukan bertindak reaktif dan mengunggu bola, tetapi bersifat proaktif dan terus mengembangkan relasi dengan media.

\section{KESIMPULAN DAN SARAN Kesimpulan}

Penelitian ini menyimpulkan bahwa Biro Humas dan Protokol Pemerintah Provinsi Sulawesi Selatan, menjalankan kegiatan media relations dengan terencana dan telah disusun dalam tugas pokok dan fungsi (tupoksi) yaitu menyiapkan bahan penyelenggaraan keterangan pers dan rencana penyelenggaraan konferensi pers; melakukan kerjasama kemitraan dengan kalangan media; menyiapkan peliputan acara kegiatan Pemerintah Provinsi Sulawesi Selatan dengan mengundang pers serta menyiapkan bahan-bahan siaran pers; menyiapkan, merencanakan dan menyebarluaskan kegiatan Pemerintah Provinsi Sulawesi Selatan dalam press release melalui media massa; melakukan pengumpulan dan penyaringan informasi sebagai bahan pengambilan kebijakan dan untuk kepentingan publikasi atau pemberitaan serta kepentingan lain; dan memberi akses kepada sumber informasi.

\section{Saran}

Saran yang diajukan penelitian ini adalah Biro Humas dan Protokol sebaiknya bertindak proaktif dan terus mengembangkan relasi dengan media serta terus berupaya memahami media massa dengan segala dinamikanya. Dengan memberikan akses sepenuhnya kepada wartawan untuk meliput dan memberitakan agenda pemerintah hanyalah sebagaian dari aktivitas media relations, tugas humas pemerintah lebih daripada itu, humas harus fokus pada berbagai kebijakan, program dan aktivitas pemerintah agar terjalin komunikasi yang baik antara publik di dalam dan di luar pemerintahan untuk menjamin penyelenggaraan pemerintahan yang transparan.

\section{REFERENSI}

Buku:

Cutlip, Scott M., Center, Allen H., \& Broom, Glen M. 2009. Effective Public Relations. Alih Bahasa Tri Wibowo. Jakarta: Kencana.

Effendy, Onong Uchjana. 2002. Hubungan Masyarakat: Suatu Studi Komunikasi. Bandung: Remaja Rosdakarya.

Gani, Rita \& Kusumalestari, Ratri Rizki. 2013. Jurnalistik Foto Suatu Pengantar. Bandung: Simbiosa.

Iriantara, Yosal. 2005. Media Relations: Konsep, Pendekatan dan Praktik. Bandung: Simbiosa.

Kurniawan, Widya Ade. 2012. Peran Humas Sekretariat Daerah Pemerintah Kota Semarang dalam Kegiatan dan Pengelolaan Media Relations. Tesis tidak diterbitkan. Semarang: Program Pascasarjana Hubungan Masyarakat Universitas Diponegoro

Kusumaningrat, Hikmat. \& Kusumaningrat, Purnama. 2007. Jurnalistik: Teori dan Praktik. Bandung: Remaja Rosdakarya.

Littlejohn, Stephen. W. \& Foss, Karen. A. 2011. Teori Komunikasi. Alih Bahasa Mohammad Yusuf Hamdan. Jakarta: Salemba Humanika.

Lewis, Philip V. 1980. Organizational Communication: The Essence of Effective Management. Second

Edition. Columbus: Grid Publishing.

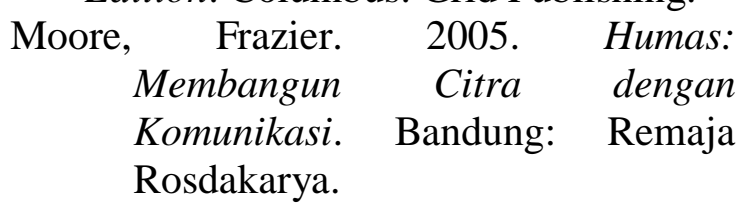


Ruslan, Rosady. 1995. Aspek-aspek Hukum dan Etika dalam Aktivitas

Public Relations Kehumasan. Jakarta: Ghalia Indonesia.

Santana, K. Septiawan. 2005. Jurnalisme Kontemporer. Jakarta: Yayasan Obor Indonesia.

Suaedi, Falih. \& Wardiyanto, Bintoro. 2010. Revitalisasi Administrasi Negara (Reformasi Birokrasi dan eGovernance). Yogyakarta: Graha Ilmu.

\section{Internet:}

Kriyantono, Rahmat. Public Relations Humas Simetris dan Objektivitas Berita.

(http://rahmatkriyantono.lecture.u b.ac.id, diakses 9 Juli 2014).

Lubis, Evawani Elysa. 2012. Peran Humas dalam Membentuk Citra Pemerintah. Jurnal Ilmu Administrasi Negara. Vol 3, No. 1. (http://library.binus.ac.id, diakses 2 Februari 2014).

www.antarasulsel.com/berita/51292/p emprov-sulsel-ajukan-apbd2014-rp579-triliun (diakses 11 Desember 2013).

Peraturan Daerah Provinsi Sulawesi Selatan Nomor 6 Tahun 2008 tentang Organisasi dan Tata Kerja Sekretariat Daerah Provinsi Sulawesi Selatan

Peraturan Menteri Dalam Negeri

Nomor 13 Tahun 2011 tentang

Pedoman Pelaksanaan Tugas

Kehumasan di Lingkungan

Kementerian Dalam Negeri dan Pemerintah Daerah

Peraturan Menteri Dalam Negeri Nomor 35 Tahun 2010 tentang Pedoman Pengelolaan Pelayanan Informasi Dan Dokumentasi Di Lingkungan Kementerian Dalam Negeri Dan Pemerintahan Daerah

Undang-Undang Nomor 14 Tahun 2008 tentang Keterbukaan Informasi Publik

\section{LAMPIRAN}

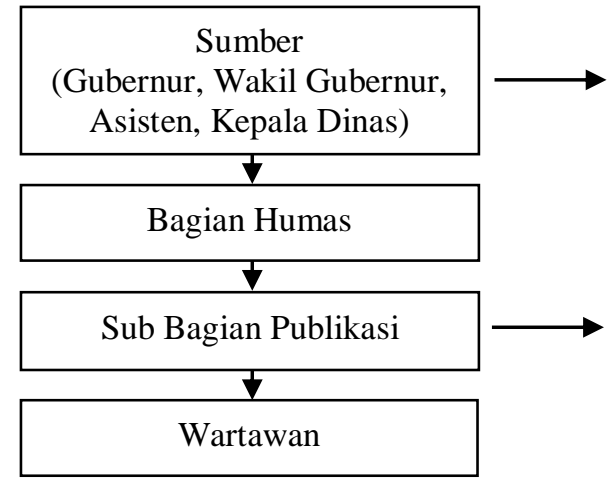

Sumber: Data hasil wawancara, 201 merencanakan / mengusulkan membuat jadwal pelaksanaan (waktu dan tempat) dan menyiapkan halhal yang akan disampaikan pers

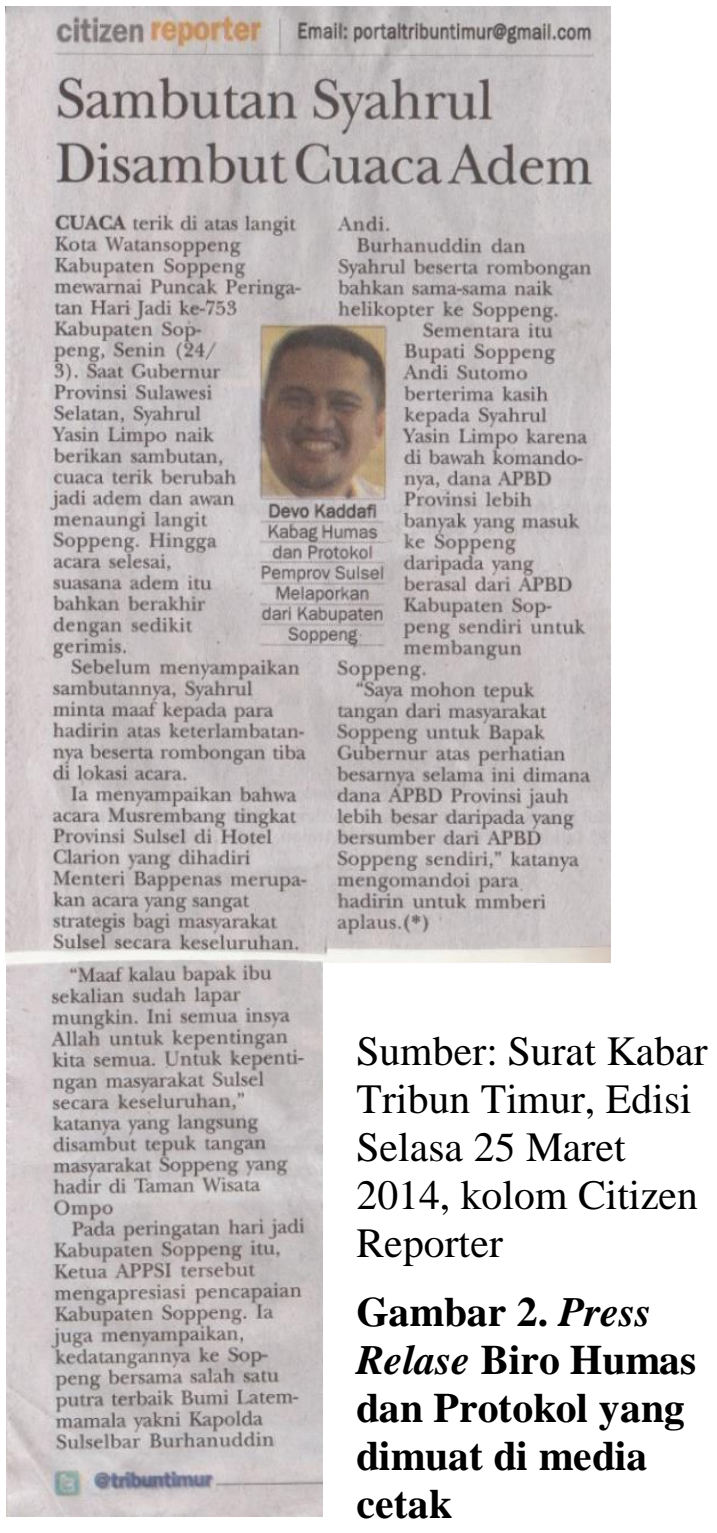

